УДК 553.493.531+553.493.6 (571.6)

\title{
РЕДКОЗЕМЕЛЬНЫЕ ЭЛЕМЕНТЫ В ПОРОДАХ И РУДАХ ИНГИЛИЙСКОГО РУДНОГО УЗЛА (Хабаровский край)
}

\author{
Черепанов А. А., Бердников Н. В. \\ ФГБУН Институт тектоники и геофизики им. Ю. А. Косыгина ДВО РАН, г. Хабаровск \\ E-mail: nick@itig.as.khb.ru
}

Приведены результаты исследований концентраций и форм нахождения редкоземельных элементов, редких и благородных металлов в породах Ингилийского рудного узла (Хабаровский край, Дальний Восток России). Показано, что РЗЭ в них присутствуют в двух основных формах: минеральной (апатит, бадделеит, фосфаты) и ионно-сорбционной, связанной с глинистыми минералами. Оба носителя РЗЭ сформировались при разрушении магматических пород Ингилийского массива, последующем размыве и перемещении компонентов коры выветривания. Оценено содержание ионно-сорбционного компонента РЗЭ в рыхлых карстовых рудах.

Ключевые слова: Ингилийский массив, Алгаминское месторождение, коры выветривания, редкоземельные элементы, благородные металлы, ионно-сорбционные руды.

DOI: $10.34078 / 1814-0998-2020-3-28-35$

Известно, что глины кор выветривания способны сорбировать редкоземельные элементы (РЗЭ), находящиеся в растворенном (ионном) состоянии. Это свойство глин успешно используется добывающей промышленностью Китая, в южных районах которого широко распространены коры выветривания по гранитам. Глины этих кор содержат значительные количества РЗЭ (так называемые ионно-сорбционные руды), для получения из них промышленного концентрата применяют простую, но весьма эффективную технологию (Bao, Zhao, 2008).

Объекты с промышленными содержаниями РЗЭ в России, как правило, расположены в труднодоступных, экономически не освоенных районах, технологии переработки их руд сложны и дорогостоящи. В связи с этим поиск и изучение новых природных источников легко обогатимых руд редкоземельных элементов представляется актуальным.

Проведенные нами предварительные исследования в различной степени выветрелых пород Дальневосточного региона, содержащих 200400 г/т РЗЭ, показали, что практически «свежие» породы содержат не более 1 мас.\%, а интенсивно выветрелые разности - до 79 мас.\% ионносорбционных редкоземелов от общего количества РЗЭ (Черепанов, 2019). Опыты по получению из них концентрата с высоким содержанием РЗЭ по технологии (Bao, Zhao, 2008) дали положительный результат (Черепанов, 2019).

(C) Черепанов А. А., Бердников Н. В., 2020
В настоящей работе приведены результаты исследований пород и руд Ингилийского рудного узла с целью определить в них концентрации и формы нахождения редкоземельных, редких и благородных металлов, а также оценить их с точки зрения применимости к их переработке технологии обогащения ионно-сорбционных руд.

\section{МАТЕРИАЛ И МЕТОДЫ ИССЛЕДОВАНИЯ}

Для исследования использованы образцы пород и руд Ингилийского щелочного массива, рудопроявления Алгама, а также пробы гравитационного концентрата циркониевой руды, любезно предоставленные нам сотрудниками АО «Дальневосточное ПГО». Всего проанализировано 19 проб руды месторождения Алгама, 6 проб гравитационных концентратов и 8 образцов пород Ингилийского массива.

В Хабаровском инновационно-аналитическом центре коллективного пользования ИТиГ ДВО РАН в образцах методом РФА (прибор S4 Pioneer, Брукер, Германия, аналитик Л. М. Ильин) определены содержания главных породообразующих оксидов, методом ICP-MS (прибор ELAN 9000, Перкин Элмер, Канада, аналитик А. В. Штарева) - концентрации редких, редкоземельных и рассеянных элементов, благородных металлов. С помощью электронной сканирующей микроскопии (микроскоп VEGA 3 LMH, TESCAN, Чехия с энергодисперсионным спектрометром X-max 80, Оксфорд, Великобритания, оператор В. О. Крутикова) изучены формы выделения и состав минералов-носителей полезных компонентов. 
Химическую подготовку проб к анализам выполняли Н. И. Ильина, А. Ю. Петрова, Г. Ф. Золотухина. При построении спайдер-диаграмм нормирование проводилось по хондриту (Тейлор, Мак-Леннан, 1988; Sun, McDonough, 1989), аномалию европия рассчитывали по формуле $\mathrm{Eu}_{\mathrm{n}}$ / $\mathrm{Eu}_{\mathrm{n}} * 2 \mathrm{Eu}_{\mathrm{n}} /\left(\mathrm{Sm}_{\mathrm{n}}+\mathrm{Gd}_{\mathrm{n}}\right)$.

\section{ГЕОЛОГИЧЕСКАЯ ХАРАКТЕРИСТИКА РАЙОНА ИССЛЕДОВАНИЯ}

Ингилийский рудный узел расположен в Аяно-Майском районе Хабаровского края, в
130 км севернее пос. Нелькан. Он является частью купольной структуры в восточной части Сибирской платформы, в зоне ее сочленения с Юдомо-Майским перикратонным прогибом. В ядре купола обнажаются протерозойские стратифицированные образования, прорванные телами щелочных базит-ультрабазитов протерозойского возраста и палеозойскими дайками габбро-диоритов. Обрамление купола сложено кембрийскими осадочными породами (рис. 1).

Раннепротерозойские метаморфические образования представлены скаполит-амфибол-пла-

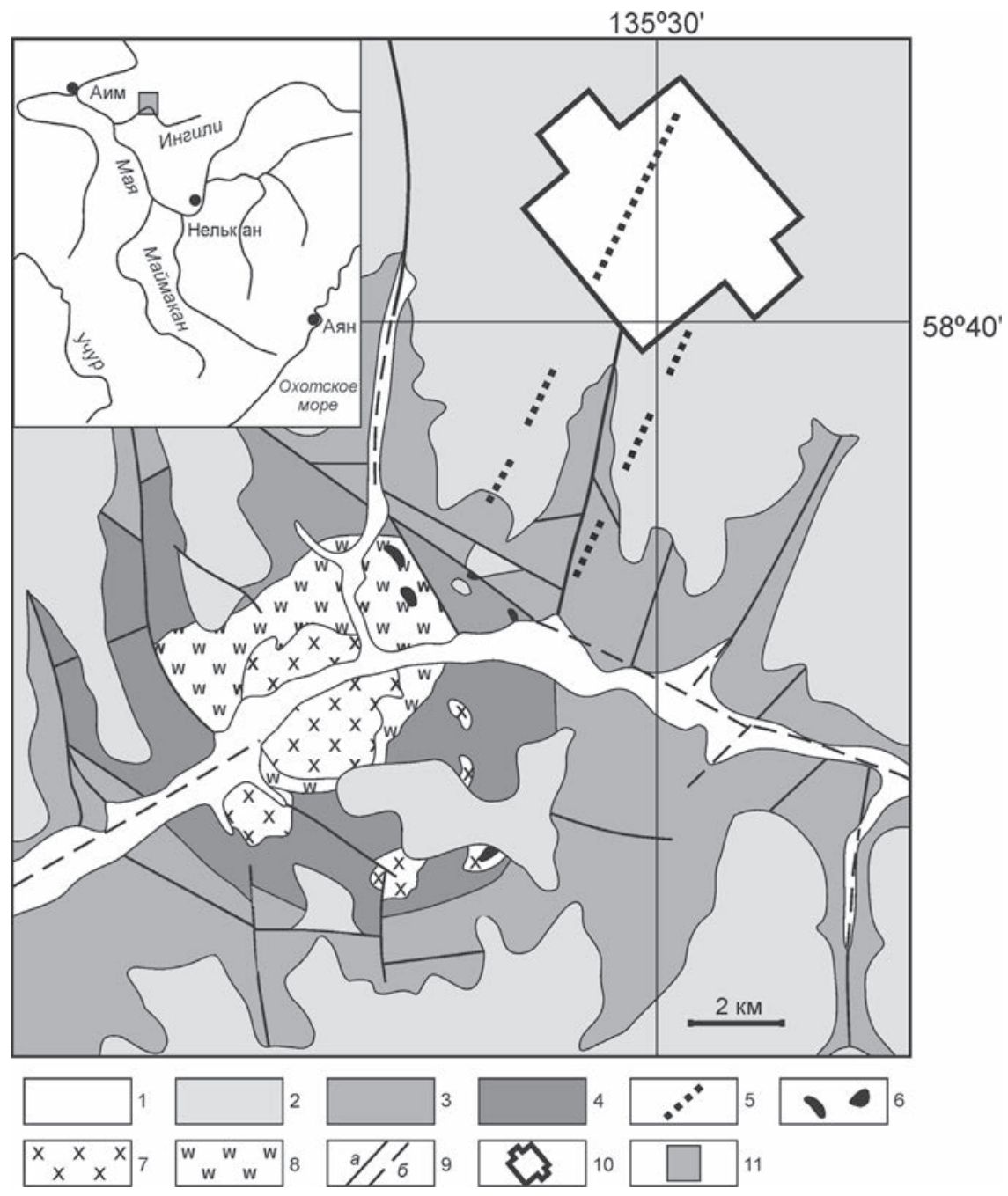

Puc. 1. Схематическая геологическая карта Ингилийского рудного узла составлена по Геологической карте Ингилийского рудного района м-ба 1:100 000 (отв. исп. Л. С. Вязунов, 2016 г.) с упрощениями: 1 - четвертичные образования; 2 - ранне-, среднекембрийские юдомская и пестроцветная свиты; 3 - средне-, позднепротерозойские породы керпыльской, майской и уйской серии; 4 - раннепротерозойская батомгская серия; 5 - дайки габбро-диоритов; 6 - тела карбонатитов; 7 - щелочные основные-ультраосновные породы Ингилийского массива; 8 - контактово-измененные породы; 9 - разломы закартированные $(a)$ и перекрытые четвертичными отложениями (б); 10 - участок «Алгама» с Алгаминским месторождением циркония; 11 - район работ на врезке

Fig. 1. The schematic geological map of Inghili ore knot is made after the geological map of the Inghili ore district 1:100 000, L. S. Vjasunov, 2016, with reductions: 1 - Quaternary formations; 2 - Early and Middle Cambrian Yudoma and Pestro-zvetnaya suites; 3 - Middle to Late Proterozoic rocks of Kerpylskaja, Mayskaya, and Uyskaya units; 4 - Early Proterozoic Batomgskaya unit; 5 - gabbro-diorite dykes; 6 - carbonatite bodies; 7 - alcaline basic and ultrabasic rocks of the Ingili massif; 8 - contact altered rocks; 9 - faults mapped $(a)$ and covered by Quaternary sediments (б); 10 - Algama site with the Algama zircon deposit; 11 - work area on the inset 
гиоклазовыми гнейсами, кристаллосланцами, амфиболитами и мраморами батомгской серии. Породы интенсивно мигматизированы мелкими телами и прожилками гнейсовидных плагио-гранитов. На них с резким угловым несогласием залегают слабометаморфизованные средне-, позднепротерозойские терригенно-карбонатные породы керпыльской, учурской, майской и уйской серий. Существенно карбонатные вендские отложения юдомской свиты несогласно перекрывают породы рифея и раннего протерозоя. Формированию пород этой свиты предшествовал крупный перерыв в осадконакоплении, сопровождавшийся становлением интрузий ингилийского комплекса (щелочные основныеультраосновные породы Ингилийского массива с небольшими телами карбонатитов) с образованием Ингилийской купольной структуры. Ее положение контролируется пересечением глубинных Ураханского и Учуро-Ингилийского разломов (Мильто, 1961; Багдасаров, 1994; Буряк и др., 1999). Формирование Ингилийского купола завершилось в девоне внедрением даек габбро-диоритов повышенной щелочности.

В верхней подсвите юдомской свиты, сложенной в основном доломитами и известковистыми доломитами, локализовано Алгаминское месторождение циркония (см. рис. 1). Протолитом доломитов явились прибрежномелководные хемогенно-карбонатные осадки, образовавшиеся под влиянием сноса продуктов выветривания магматитов ингилийского комплекса (Буряк и др., 1999). В карбонатах юдомской свиты отмечены зоны карстов, приуроченные к разрывным нарушениям и дайкам габбро-диоритов (Л. С. Вязунов, 2016 г.). Карстовые полости выполнены кольматолитами - гравитационнообъемными брекчиями, инфлювием и хемогенным материалом, который представляет собой материал дезинтеграции доломитов юдомской свиты и гипергенного выветривания даек. На территории участка «Алгама» (см. рис. 1) они обогащены цирконием и представляют собой руды Алгаминского месторождения. Рудные тела имеют линзовидную, пластообразную форму, мощность от первых сантиметров до 28 м и встречаются на различных гипсометрических
Таблица 1. Химический состав руд Table 1. Chemical composition of ores

\begin{tabular}{|c|c|c|c|}
\hline $3(3)$ & $4(8)$ & $5(8)$ & $6(6)$ \\
\hline 27.61 & 21.94 & 33.13 & 34.41 \\
\hline 0.02 & 0.05 & 0.05 & 0.05 \\
\hline H. O. & H. o. & H. O. & 42.40 \\
\hline 0.31 & 0.47 & 0.81 & 1.67 \\
\hline 0.63 & 0.92 & 1.73 & 0.96 \\
\hline 0.04 & 0.39 & 0.40 & 0.20 \\
\hline 25.07 & 33.67 & 30.32 & 2.81 \\
\hline 17.52 & 9.55 & 6.25 & 3.31 \\
\hline 0.06 & 0.08 & 0.84 & 5.16 \\
\hline 0.02 & 0.09 & 0.10 & 0.04 \\
\hline 0.01 & 0.03 & 0.31 & 1.05 \\
\hline 31.39 & 33.96 & 27.06 & 7.44 \\
\hline 102.68 & 101.15 & 101.00 & 99.51 \\
\hline 0.62 & 3.52 & 70.99 & 66.94 \\
\hline 1.38 & 5.59 & 12.31 & 49.41 \\
\hline 0.14 & 1.60 & 2.91 & 16.61 \\
\hline 0.66 & 4.68 & 12.02 & 72.81 \\
\hline 0.13 & 0.87 & 2.81 & 15.13 \\
\hline 0.03 & 0.23 & 0.87 & 3.62 \\
\hline 0.17 & 1.03 & 4.28 & 16.30 \\
\hline 0.02 & 0.13 & 0.65 & 2.23 \\
\hline 0.13 & 0.68 & 3.85 & 13.30 \\
\hline 0.03 & 0.14 & 0.78 & 2.83 \\
\hline 0.07 & 0.35 & 1.97 & 8.12 \\
\hline 0.01 & 0.04 & 0.24 & 1.04 \\
\hline 0.05 & 0.21 & 1.30 & 6.58 \\
\hline 0.01 & 0.03 & 0.19 & 0.92 \\
\hline 0.88 & 4.72 & 31.98 & 119.60 \\
\hline
\end{tabular}

\begin{tabular}{l|c|c|c}
0.67 & 17.22 & 0.88 \\
\hline
\end{tabular}

нгилийского массива (1) и даек 5 - рыхлая циркониевая руда из карстовой полости; 6 - циркониевый благородные - в г/т. В скобках - количество проб в выборке, н. о. - не

уровнях от 560 до 620 м. Главная залежь локализована в северной части рудного поля, ее протяженность 5.8 км при ширине 500-800 м и средней мощности 1.6 м. Содержание $\mathrm{ZrO}_{2}$ в ней колеблется от 0.9 до 55 мас.\%.

Циркониевый потенциал этих руд хорошо изучен Л. С. Вязуновым (2016 г.), однако их ценность может быть повышена благодаря попутному выделению из них благородных металлов и редкоземельных элементов.

\section{РЕЗУЛЬТАТЫ ИССЛЕДОВАНИЙ}

Чтобы проследить геолого-геохимическую историю формирования карстовых руд Алгаминского месторождения и оценить их перспективность на благородные металлы и редкоземельные элементы, мы изучили коллекцию, состоящую из щелочных габброидов Ингилийского массива и даек, доломитов юдомской свиты, дезинтегрированных доломитов, рыхлой циркониевой руды из 
и пород месторождения Алгама

and rocks of the Algama deposit

\begin{tabular}{|l|r|r|r|r|r|r|}
\hline $\begin{array}{c}\text { Оксиды, } \\
\text { элементы }\end{array}$ & $1(2)$ & $2(2)$ & $3(3)$ & $4(8)$ & $5(8)$ & \multicolumn{1}{|c|}{$6(6)$} \\
\hline $\mathbf{\Sigma} \mathbf{P 3}+\mathbf{Y}$ & $\mathbf{3 5 6 . 0 7}$ & $\mathbf{1 7 5 . 0 2}$ & $\mathbf{4 . 3 3}$ & $\mathbf{2 3 . 8 2}$ & $\mathbf{1 4 7 . 1 5}$ & $\mathbf{3 9 5 . 4 4}$ \\
\hline $\mathrm{Sc}$ & 29.72 & 10.74 & 0.03 & 0.72 & 13.71 & 111.22 \\
\hline $\mathrm{V}$ & 184.06 & 64.44 & 1.79 & 10.48 & 20.64 & 85.28 \\
\hline $\mathrm{Cr}$ & 153.74 & 89.55 & 38.01 & 33.61 & 33.08 & 19.19 \\
\hline $\mathrm{Co}$ & 38.90 & 17.72 & 4.96 & 7.99 & 9.44 & 6.08 \\
\hline $\mathrm{Ni}$ & 270.66 & 16.79 & 5.22 & 17.07 & 31.66 & 33.18 \\
\hline $\mathrm{Cu}$ & 109.80 & 23.92 & 7.12 & 29.47 & 42.86 & 76.63 \\
\hline $\mathrm{Zn}$ & 144.77 & 44.70 & 4.93 & 29.69 & 63.45 & 34.63 \\
\hline $\mathrm{Ga}$ & 19.76 & 16.02 & 0.24 & 0.74 & 2.06 & 12.10 \\
\hline $\mathrm{Rb}$ & 46.20 & 66.05 & 0.70 & 2.08 & 2.56 & 1.72 \\
\hline $\mathrm{Sr}$ & 720.53 & 226.85 & 31.19 & 42.39 & 24.48 & 205.80 \\
\hline $\mathrm{Zr}$ & 653.69 & 3095.96 & 135.41 & 643.5 & 8221.42 & 424000 \\
\hline $\mathrm{Nb}$ & 56.16 & 50.33 & 2.21 & 4.79 & 265.01 & 2402.41 \\
\hline $\mathrm{Ag}$ & 1.78 & 4.73 & 5.39 & 0.82 & 13.00 & 124.74 \\
\hline $\mathrm{Sn}$ & 2.47 & 3.70 & 0.34 & 0.65 & 0.48 & 0.54 \\
\hline $\mathrm{Cs}$ & 0.51 & 9.06 & 0.05 & 0.14 & 0.23 & 0.18 \\
\hline $\mathrm{Ba}$ & 641.84 & 401.13 & 3.66 & 300 & 295.85 & 272.30 \\
\hline $\mathrm{Hf}$ & 17.33 & 59.11 & 2.61 & 12.81 & 545.43 & 4991.15 \\
\hline $\mathrm{Ta}$ & 4.57 & 1.14 & 0.05 & 0.07 & 0.11 & 0.03 \\
\hline $\mathrm{W}$ & $\mathrm{H} . \mathrm{o}$. & 113.84 & 20.89 & 37.97 & 456.92 & 4690.05 \\
\hline $\mathrm{Pb}$ & 9.90 & 15.61 & 2.73 & 2.95 & 3.61 & 33.49 \\
\hline $\mathrm{Th}$ & 5.21 & 10.23 & 0.05 & 1.07 & 0.34 & 0.37 \\
\hline $\mathrm{U}$ & 4.25 & 5.05 & 0.98 & 7.41 & 78.52 & 438.78 \\
\hline $\mathrm{Pd}$ & 0.050 & 0.032 & 0.001 & 0.002 & 0.138 & 0.007 \\
\hline $\mathrm{Ir}$ & $<0.001$ & 0.013 & $<0.001$ & 0.004 & 0.054 & 0.093 \\
\hline $\mathrm{Pt}$ & 0.063 & 0.031 & 0.001 & 0.012 & 0.129 & 0.214 \\
\hline $\mathrm{Au}$ & 0.786 & 0.055 & 0.115 & 0.230 & 0.039 & 0.063 \\
\hline
\end{tabular}

(2); 3 - доломиты юдомской свиты; 4 - дезинтегрированные доломиты; концентрат. Породообразующие - в мас. \%, редкие, редкоземельные и определялось.

карстовой полости и циркониевого концентрата. Средние составы этих пород показаны в табл. 1.

Щелочные габброиды Ингилийского массива представлены апатитсодержащими габбропироксенитами, а дайки - щелочными габбродиоритами. Распределение редких и рассеянных элементов в этих породах показывает значительное обогащение литофильными элементами, в том числе цирконием, которого больше в габбродиоритах (рис. 2, a). Для распределения в них РЗЭ характерно преобладание легких и средних РЗЭ (рис. $3, a$ ) с незначительной отрицательной аномалией $\mathrm{Eu}(0.75$ в габбро-пироксенитах и 0.64 в габбро-диоритах) и характерной сменой направления тренда с отрицательного на положительный в левой его части (от Тm до Ү). Носителями РЗЭ в этих породах являются циркон, пирохлор, кобеит, сфен, апатит.

Распределение редких и рассеянных элементов в габбро-диоритах сходно с таковым в щелоч- ных габбро-пироксенитах (см. рис. $2, a)$. Отличие состоит в большем обогащении этих пород цирконием и гафнием и более интенсивном обеднении халькофильными и сидерофильными элементами (V, $\mathrm{Cr}, \mathrm{Co}, \mathrm{Ni})$. Сумма Р3Э + Y в них в среднем вдвое меньше, чем в габбро-пироксенитах, преобладание легких и средних РЗЭ над тяжелыми выражено слабее.

Доломиты юдомской свиты массивные тонкозернистые породы, часто слабо брекчированные с кальцитовым и кварцевым цементом. В их составе присутствует терригенный материал, поступавший из коры выветривания пород Ингилийского массива, в пользу чего свидетельствуют находки в них зерен бадделеита и платины (рис. 4, $a, \sigma)$. Об этом же говорит распределение в них редких, редкоземельных и рассеянных элементов, в общих чертах сходное с таковым в магматитах Ингилийского массива, включая европиевый минимум и характерную смену направления тренда РЗЭ с отрицательного на положительный в левой его части (см. рис. $2, \sigma ; 3, \sigma)$.

Дезинтегрированные доломиты и рыхлая циркониевая руда из карстовой полости отражают последовательные этапы разрушения доломитов. Дезинтегрированные доломиты представляют собой брекчии доломитов с бадделеитглинистым, кварцевым или кальцит-кварцевым цементом (рис. 4, в). В основном это так называемые твердые руды либо инфлювий карстовых пустот. Рыхлые руды состоят из известковоглинистого материала, дресвы и рудных брекчий с бадделеит-глинистым цементом, пропитанных гидроксидами железа. Гравитационный концентрат представляет собой мелко-тонкозернистый ожелезненный песок.

Как видно из рис. 2,6 , процесс дезинтеграции доломитов сопровождается повышением содержаний в продуктах разрушения, в первую очередь $\mathrm{Nb}, \mathrm{Zr}$ и Hf, а также Sc и V. Параллельно в них происходит накопление редкоземельных элементов. Резко отрицательная аномалия Се указывает на поступление материала из коры выветривания (Тейлор, Мак-Леннан, 1988).

Строгой закономерности в содержаниях благородных металлов в изученных породах не об- 

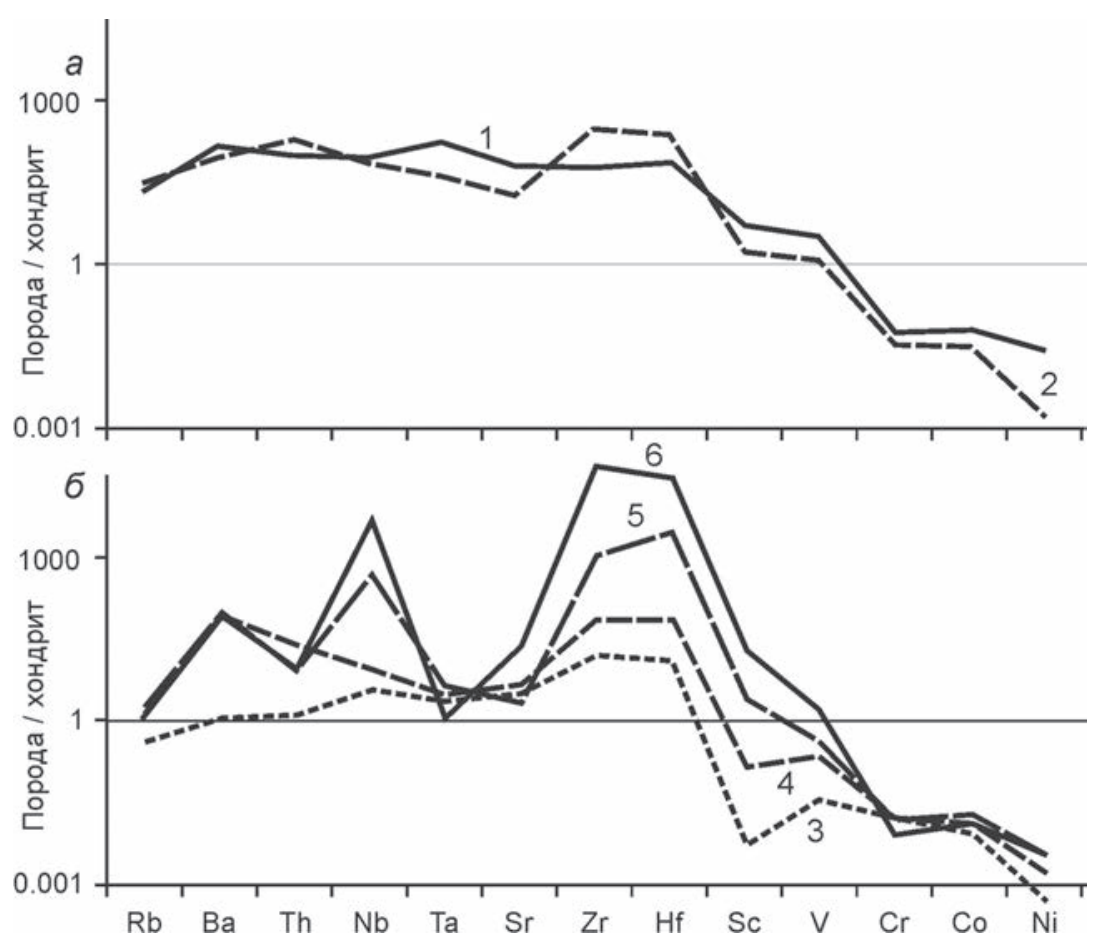

Puc. 2. Распределение редких и рассеянных элементов в изученных породах. Здесь и далее цифры у линий соответствуют номерам выборок в табл. 1

Fig. 2. Distribution of dissipated and rare elements in studied rocks. Henceforth, numbers of lines correspond to the numbers of rocks in Table 1
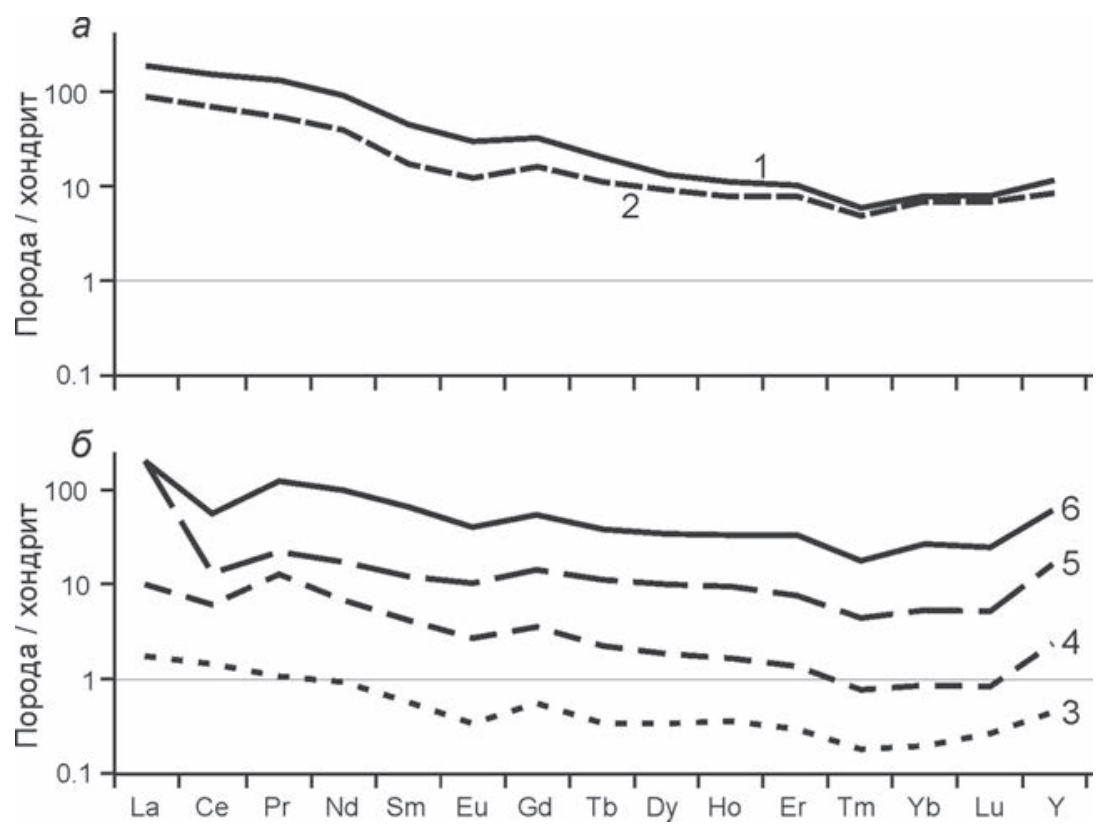

Рuc. 3. Распределение РЗЭ + Ү в изученных породах

Fig. 3. Distribution of REE $+\mathrm{Y}$ in studied rocks

наружено. Вероятнее всего, это связано с тем, что благородные металлы в доломитах и продуктах их выветривания заимствованы из магматических пород Ингилийского массива в виде редких немногочисленных зерен (см. рис. 4, б). При- мененная методика анализа на благородные металлы предполагает аналитическую навеску 2 г, что обусловливает низкую вероятность попадания в нее зерен $\mathrm{Au}$ и/или Pt. Тем не менее можно констатировать, что наиболее обогащенными золотом являются габбро-пироксениты (0.786 г/т), а платиной - циркониевый концентрат $(0.214$ г/т). Высокие концентрации золота встречены в отдельных образцах доломитов (до 0.24 г/т) и дезинтегрированных доломитов (до 1.8 г/т), в образцах рыхлых руд отмечаются повышенные содержания платины (до 0.57 г/т) и палладия $(1.06$ г/т).

\section{ОБСУЖДЕНИЕ РЕЗУЛЬТАТОВ}

Руды Алгаминского месторождения и продукты их переработки (гравиконцентрат) содержат Р3Э в двух формах. Первая - минеральная (апатит, баддеилит, фосфаты) детритная, вторая - ионно-сорбционная, связанная с глинистыми минералами. Оба носителя Р3Э сформировались при выветривании пород Ингилийского массива, последующем разрушении и перемещении компонентов коры выветривания. Минеральная форма преобладает в гравитационном концентрате, ионно-сорбционная, предположительно, должна преобладать в обогащенных глинистыми компонентами рыхлых карстовых рудах. Подобные процессы наблюдались на месторождении Томтор (Якутия), где размыв коры выветривания по обогащенным РЗЭ карбонатитам привел к гидрохимическому осаждению и накоплению во впадинах осадков с содержанием РЗЭ до 12 мас.\% (Толстов и др., 2011).

Выделение Р3Э из собственных минеральных фаз или из минералов, где они присутствуют в качестве изоморфных примесей, сложно и трудоемко. В то же время технология обогащения ионносорбционных руд проста и малозатратна (Вао, Zhao, 2008; Быховский, 2014). Ее основой явля- 

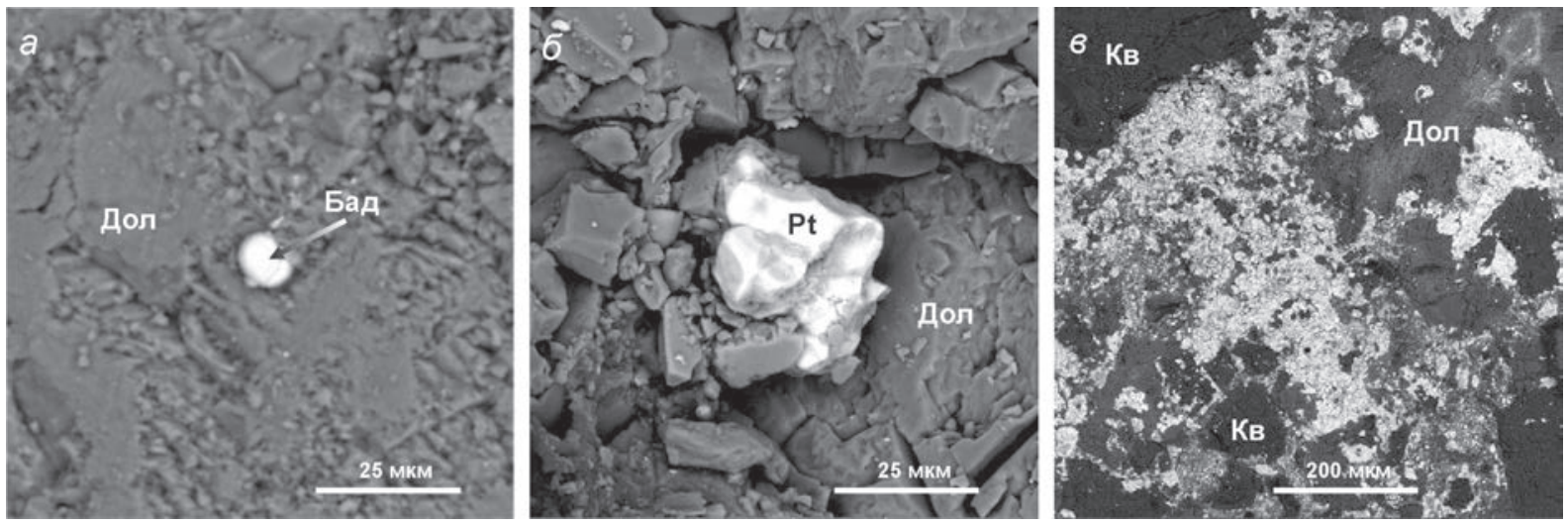

Puc. 4. Зерна бадделеита (a) и платины (б) в доломите юдомской свиты; в - кварц-карбонатная брекчия с бадделеит-циркониевым цементом (белое). Бад - бадделеит, Кв - кварц, Дол - доломит, $\mathrm{Pt}$ - платина

Fig. 4. Baddeleyite ( $a$ ) and platinum ( $\sigma$ ) grains in the Yudoma suite dolomite; $в$ - quartz-carbonate breccia with baddeleyite-zircon cement (white). Бад - baddeleyite, Кв - quartz, Дол - dolomite, Pt - platinum

Таблица 2. Содержание $\mathbf{P} 3 Э+\mathrm{Y}$ в минеральной и ионно-сорбционной форме в карстовых рудах и гравитационном концентрате Алгаминского месторождения

Table 2. PEE $+\mathbf{Y}$ in mineral and ionic-sorption forms in karst ores and gravitational concentrate of the Algama deposit

\begin{tabular}{|c|c|c|c|c|c|c|}
\hline \multirow{2}{*}{\multicolumn{2}{|c|}{ Характеристика исходного материала }} & \multirow[t]{2}{*}{$\begin{array}{l}\text { Сумма РЗЭ } \\
+ \text { Y } \\
\text { в пробе, г/т }\end{array}$} & \multirow{2}{*}{$\begin{array}{c}\text { РЗЭ + Y } \\
\text { в минераль- } \\
\text { ной форме, } \\
\text { г/т }\end{array}$} & \multirow{2}{*}{$\begin{array}{c}\text { РЗЭ + Y } \\
\text { в ионно- } \\
\text { сорбционной } \\
\text { форме, г/т }\end{array}$} & \multicolumn{2}{|c|}{$\begin{array}{c}\text { Содержание ионно- } \\
\text { сорбционного компонента, } \\
\text { мас. \% }\end{array}$} \\
\hline & & & & & в пробах & среднее \\
\hline \multirow{2}{*}{$\begin{array}{l}\text { Рыхлые карстовые } \\
\text { руды }\end{array}$} & проба 1 & 113.80 & 35.60 & 78.16 & 68.68 & \multirow{2}{*}{70.41} \\
\hline & проба 2 & 247.29 & 68.90 & 178.39 & 72.13 & \\
\hline \multirow{3}{*}{$\begin{array}{l}\text { Гравитационный } \\
\text { концентрат }\end{array}$} & проба 1 & 454.97 & 353.56 & 141.41 & 31.08 & \multirow{3}{*}{32.42} \\
\hline & проба 2 & 355.87 & 227.60 & 128.27 & 36.04 & \\
\hline & проба 3 & 411.06 & 278.12 & 123.94 & 30.15 & \\
\hline
\end{tabular}

ется обработка руд сульфатом натрия для перевода сорбированных РЗЭ + Ү в раствор и затем щавелевой кислотой для их осаждения в виде оксалатов. Результаты оценки ионно-сорбционного потенциала алгаминских руд по этой технологии (Черепанов, 2019) показаны в табл. 2.

Как видно из табл. 2, в рыхлых карстовых рудах Алгаминского месторождения содержание ионно-сорбционных РЗЭ составило в среднем 70.41 мас.\%, а в пробах гравитационного концентрата -32.42 мас.\%. Полученный результат закономерен, поскольку при гравитационном обогащении в концентрате происходит накопление обогащенных РЗЭ минералов песчаной фракции и удаление тонкозернистой глинистой составляющей. Напротив, глинистая фракция рыхлых карстовых руд заключает в себе большую часть их редкоземельного потенциала в ионносорбционной форме. Таким образом, открывается возможность эффективного использования не только гравитационного циркониевого концентрата, но и глинистых хвостов его обогащения, содержащих большое количество легко выделяемых РЗЭ.
На территории Ингилийского рудного узла целесообразно провести поиск мест возможного захоронения продуктов размыва кор выветривания, обогащенных редкоземельными элементами. При этом необходимо учитывать, что эти захоронения могут формировать не только типичные вторичные месторождения в корах выветривания непосредственно на материнских породах или в депрессионных структурах на их периферии, но и проявления, связанные с хемогенным переносом полезного компонента на относительно большие расстояния. В пределах территории Алгаминского месторождения такие проявления с большой долей вероятности могут присутствовать вдоль даек габбро-диоритов, где положительные формы рельефа создавали своеобразные преграды движению потоков и способствовали осаждению переносимого ими глинистого материала, сорбирующего РЗЭ.

\section{ВЫВОДЫ}

1. Редкоземельные элементы $(+Y)$ в рудах Алгаминского месторождения присутствуют в двух основных формах: минеральной (апатит, бадде- 
леит, фосфаты) и ионно-сорбционной, связанной с глинистыми минералами.

2. Основным источником РЗЭ, редких элементов и благородных металлов в рудах месторождения являются древние коры выветривания, формировавшиеся при разрушении магматических пород Ингилийского массива.

3. РЗЭ + Ү в ионно-сорбционной форме концентрируются в глинистом компоненте рыхлых карстовых руд.

3. Целесообразен поиск погребенных кор выветривания как в пределах Ингилийского массива (ложбины выветривания над карбонатитами), так и за его пределами (вдоль даек габбродиоритов).

4. Высокие концентрации ионно-сорбционных РЗЭ в рудах Алгаминского месторождения предполагают возможность их попутного извлечения с помощью малозатратной технологии.

\section{БЛАГОДАРНОСТЬ}

Авторы благодарят сотрудников ОА «Дальневосточное ПГО» и ДВ ТФГУ В.Е. Кузнецова, В. В. Оскарева и М. В. Мартынюка за ценные консультации и передачу проб для исследований.

\section{ЛИТЕРАТУРА}

Багдасаров Ю. А. Ингилийско-Алгаминский узел Восточного Алдана // Отечественная геология. 1994. № 1. C. 18-28.
Буряк В. А., Беспалов В. Я., Гагаев В. Н., Зарубин Б. А., Троян В. Б. Новый геолого-промышленный тип циркониевого оруденения (условия образования, перспективы использования). Хабаровск, 1999. 216 с.

Быховский Л. 3. Реальные, потенциальные и перспективные источники редкоземельного сырья в России // Минеральные ресурсы России. Экономика и управление. 2014. № 4. С. 2-8.

Мильто А. Н. Государственная геологическая карта м-ба 1:200 000. Лист О-53-Х. 1961.

Тейлор С. Р., Мак-Леннан С. М. Континентальная кора: ее состав и эволюция. Москва : Мир, 1988. 384 с.

Толстов А. В., Коноплев А. Д., Кузьмин В. И. Особенности формирования уникального редкометалльного месторождения Томтор и оценка перспектив его освоения // Разведка и охрана недр. 2011. № 6. С. 20-26.

Черепанов А. А. Оценка возможности применения технологии переработки «ионных» руд для извлечения редкоземельных элементов из пород Дальнего Востока // Тектоника, глубинное строение и минерагения Востока Азии / Х Косыгинские чтения : Материалы Всерос. конф. Хабаровск : ИТиГ ДВО РАН, 2019. C. 236-239.

Bao Z., Zhao Z. Geochemistry and mineralization with exchangeable REY in the weathering crusts of granitic rocks in South China // Ore Geology Reviews. 2008. Vol. 33. P. 519-535.

Sun S. S., McDonough W. F. Chemical and isotopic systematics of oceanic basalts: implications for mantle composition and processes // Magmatism in the oceanic basins / eds. A. D. Saunders, M. J. Norry. Geol. Soc. Spec. Publ. 1989. No. 42. P. 313-345.

\title{
RARE-EARTH ELEMENTS IN ROCKS AND ORES OF THE INGHILI ORE AREA (Khabarovsk Krai)
}

\section{A. A. Cherepanov, N. V. Berdnikov}

\author{
Yu. A. Kosygin Institute of Tectonics and Geophysics, FEB RAS, Khabarovsk
}

Concentrations and mineral forms of rare, rare-earth (REE) elements and precious metals have been investigated in rocks of the Inghili ore knot (Khabarovsk Krai, Russia's Far East). It is shown that REE are found in the compositions of both hard minerals (apatite, baddeleite, phosphate) and clays (ionic-sorption form). Both REE forms result from erosion and displacement of residuum after destruction of magmatic rocks. Content of ionic-sorption component in friable karst ore has been estimated.

Keywords: Inghili massif, Algama deposit, residuum, rare-earth elements, precious metals, ionic-sorption ore. 


\section{REFERENCES}

Bagdasarov, Yu. A., 1994. Inghili-Algama Knot of East Aldan, Otechestvennaya Geologiya. 1, 18-28 [In Russian].

Bao, Z., Zhao, Z., 2008. Geochemistry and Mineralization with Exchangeable REY in the Weath-Ering Crusts of Granitic Rocks in South China, Ore Geology Reviews. 33, 519-535.

Buryak, V. A., Bespalov, V. Ya., Gagaev, V. N., Zarubin, B.A., Troyan, V. B., 1999. New Geological-Industrial Type of Zr Mineralization (Forming Conditions, Use Perspectives). Khabarovsk [In Russian].

Bykhovsky, L. Z., 2014. Real, Potential, and Perspective Sources of REE Raw in Russia, Mineral Resources of Russia. Economics and Administration. 4, 2-8 [In Russian].

Cherepanov, A. A., 2019. Evaluating the Possibility of Using the "Ionic" Ore Processing Technology for the Extraction of REE from Rocks in the Russian
Far East, Tectonics, Deep Structure, and Minerageny of East Asia, Proceedings of the $10^{\text {th }}$ Kosygin Readings. Khabarovsk, ITG FEB RAS, 236-239 [In Russian].

Milto, A. N., 1961. Federal Geological Map 1:200 000. Sheet O-53-X [In Russian].

Sun, S. S., McDonough, W. F., 1989. Chemical and Isotopic Systematics of Oceanic Basalts: Implications for Mantle Composition and Processes, Magmatism in the Oceanic Basins, Eds. A. D. Saunders, M. J. Norry), Geological Society Special Publications. 42, 313-345.

Taylor, S. R., McLennan, S. M., 1988. Continental Crust, Its Composition and Evolution. Moscow, Mir [In Russian].

Tolstov, A. V., Konoplev, A. D., Kuzmin, V. I., 2011. Formation Features of the Unique Tomtor Rare Metal Deposit, and Its Feasibility Estimation, Prospect and Protection of Mineral Resources. 6, 20-26 [In Russian]. 